2016

\title{
Legality, Legitimacy and Constitutional Amendment in Canada
}

Jamie Cameron

Osgoode Hall Law School of York University, jcameron@osgoode.yorku.ca

Follow this and additional works at: http:// digitalcommons.osgoode.yorku.ca/olsrps

Part of the Constitutional Law Commons

\section{Recommended Citation}

Cameron, Jamie, "Legality, Legitimacy and Constitutional Amendment in Canada" (2016). Osgoode Legal Studies Research Paper Series. 175

http://digitalcommons.osgoode.yorku.ca/olsrps/175 


\title{
OSGOODE HALL LAW SCHOOL \\ LEGAL STUDIES RESEARCH PAPER SERIES
}

Research Paper No. 1

Volume 13, Issue 1, 2017

\section{Legality, Legitimacy and Constitutional Amendment in Canada \\ Yale Law School Conference, April 2016.}

\author{
Jamie Cameron
}

This paper can be downloaded free of charge from:

http://ssrn.com/abstract=2821285

\begin{abstract}
Further information and a collection of publications from the Osgoode Hall Law School Legal Studies Research Paper Series can be found at:

http://www.ssrn.com/link/Osgoode-Hall-LEG.html
\end{abstract}

\section{Editors:}

Editor-in-Chief: Carys J. Craig (Associate Dean of Research \& Institutional Relations and Associate Professor, Osgoode Hall Law School, York University, Toronto)

Production Editor: Kiana Blake (Osgoode Hall Law School, York University, Toronto) 
Osgoode Legal Studies Research Paper No. 1

Vol. 13/ Issue. 1/ (2017)

\title{
Legality, Legitimacy and Constitutional Amendment in Canada
}

Yale Law School Conference, April 2016.

\author{
Jamie Cameron
}

\begin{abstract}
:
It is accepted that Canada's Constitution is almost impossible to amend, and that this amendment rigidity stems from the Constitution's patriation in 1982 and two failed reform initiatives, the Meech Lake and Charlottetown Accords. The high-stakes drama of 1982, threat of Quebec separation and denouement of the post-patriation Accords were events of singular urgency which have dominated the literature and consigned the longer history of amendment to the background. This article provides a corrective which explores Canada's two uneven periods of constitutional change - before and after textual rules - and in doing so theorizes that rich insights into the riddles of Canada's amendment constitutionalism are found in the interface between the legality or formality of amendment, and its legitimacy or acceptance. The article explains how the legality and legitimacy of amendment failed to align prior to patriation - when amendment was governed by a concept of statutory legality - and after patriation, when rules of constitutional legality were adopted. Though the textual amendment rules are admittedly rigid, the role legitimacy plays in Canada's amendment rigidity cannot be overlooked. As Canada approaches its sesquicentennial anniversary in 2017 there is lingering uncertainty on what is required to align the legitimacy of constitutional change with the formal criteria of amendment legality.

\section{Keywords:}

Constitutional amendment, Canadian constitutional amendment before and after patriation, legality and legitimacy in amendment constitutionalism, statutory and constitutional legality, how a lack of constitutional legality undermined the legitimacy of amendments to the Canadian Constitution.

\author{
Author(s): \\ Jamie Cameron \\ Osgoode Hall Law School, York University \\ E: jcameron@osgoode.yorku.ca
}




\title{
CANADA IN THE WORLD: COMPARATIVE PERSPECTIVES ON THE CANADIAN CONSTITUTION
}

\author{
Legality, Legitimacy and Constitutional Amendment in Canada \\ Jamie Cameron*
}

\section{Introduction}

Amendment rules are a requisite feature of constitutional text. In that regard, the British North America Act or Canada Act, 1867 stands almost alone among constitutions of the world in not prescribing rules for its amendment. ${ }^{1}$ It was not so jarring an omission when four colonies joined in federal union under a constitution enacted by the British Parliament, and were first in the British Empire to earn Dominion status. ${ }^{2}$ Over time, the text was modified twenty-one times by UK legislation before amending rules empowering Canada to change its own Constitution were added. ${ }^{3}$

\footnotetext{
*Professor, Osgoode Hall Law School. My thanks to Mr. John Wilson (JD 2016) and Mr. Tanner Stanley (JD 2018) for their valuable assistance in the preparation of this draft. I also thank Richard Albert and David Cameron for inviting me to participate in this conference.

${ }^{1}$ See Francesco Giavannoni, “Amendment Rules in Constitutions", Public Choice, 115 (2003), 37-61 (stating in 2003 that only $4 \%$ of the world's constitutions lack a formal amending process).

${ }^{2}$ British North America Act 1867, 30-31 Vict., c.3 (U.K.) [“BNA Act”] (re-named the Canada Act, 1867 in 1982). The 1867 Constitution was a hybrid of written and unwritten constitutionalism. While unwritten constitutions change informally, through a process of evolution, written constitutions prescribe amendment rules. This article is concerned with questions of amendment arising from Canada's written Constitution and its failure to prescribe rules for amendment of the text, and not with its unwritten Constitution, which is defined in the main but not exclusively by the Westminster tradition of parliamentary government.

${ }^{3}$ Canada Act 1982 (U.K.), 1982, c.11, Sched. B (“Canada Act, 1982"); Patrick J. Monahan and Byron Shaw, Constitutional Law, 4th edition. (Toronto: Irwin Law Inc., 2013), pp. 165.
} 
Patriating the Constitution, entrenching an amending formula, and enacting a Charter of Rights and Freedoms in 1982 were transformative acts of constitutional renewal. Since then the Charter has been presented to the world as a model that demonstrates how constitutional rights can be balanced against the legislature's democratic authority. ${ }^{4}$ The transformation was messy, though, and left Canada in constitutional despair when profound divisions on renewal remained a flashpoint for years after patriation.

Amendment has been a preoccupation throughout Canada's constitutional history. Before the cauldron years prior to and after patriation, the search for an amending formula had been futile and demoralizing. Against that backdrop, the importance of entrenching a formula and "bringing the Constitution home" cannot easily be overstated. ${ }^{5}$ Patriation and its successor initiatives - the Meech Lake and Charlottetown Accords - represent a legal, political, and symbolic break between defining periods of amendment history: before and after textual rules. ${ }^{6}$ That is the moment when a tradition of quiescent deadlock on constitutional change was replaced

\footnotetext{
${ }^{4}$ See generally Stephen Gardbaum, "Reassessing the New Commonwealth Model of Constitutionalism", Int/ J Constitutional Law, 8:2 (2010), 167-210; see also David S. Law and Mila Versteeg, "The Declining Influence of the United States Constitution, N.Y.U.L.Rev., 87:3 (2012), 762-858 at 801-23 (asking, "Is Canada a Constitutional Superpower" and discussing Canada's status as a "constitutional trendsetter" among common law or Commonwealth countries).

${ }^{5}$ Adding amendment rules "patriated" the Constitution by providing the legal framework for a domestic process of constitutional change. The term was reportedly used for the first time by Prime Minister Lester Pearson, who stated in 1966 that "[w]e intend to do everything we can to have the constitution of Canada patriated, or repatriated". Hansard, HC vol. 373, col. 2, 28 January 1966.

${ }^{6}$ Both Accords addressed the perceived deficits and unfinished business of 1982's patriation reforms. While the Meech Lake Accord (the "MLA") addressed Quebec's exclusion from patriation and was seen as the "Quebec Round", the Charlottetown Accord proposed comprehensive reform and is known as the "Canada Round". Canada's first ministers negotiated and reached agreement on the MLA on April 30, 1987, and ultimately it failed on June 23, 1990, at the end of a three-year ratification period. After agreement was reached on August 28, 1992, the Charolottetown Accord was voted down in a nationwide referendum held on October 26, 1992. The Accords are discussed later in the article.
} 
by a noisy contest to define Canada's constitutional core and even to break Confederation apart. The high-stakes drama of 1982, threat of Quebec separation, and denouement of the postpatriation Accords were events of singular urgency. By dominating the literature, these events consigned the longer history of amendment to the background. ${ }^{7}$

Now that the crisis years have receded, fresh insight is emerging through a process of generational renewal in the scholarship. ${ }^{8}$ This article joins that movement by exploring Canada's two uneven periods of constitutional change - before and after textual change. In drawing that longer history back into the discussion, it theorizes that rich insights into the riddles of Canada's amendment constitutionalism are found in the interface between the legality or formality of amendment, and its legitimacy or acceptance.

\footnotetext{
${ }^{7}$ See, e.g., Keith Banning and Richard Simeon (eds.), And No One Cheered: Federalism, Democracy and the Constitution Act (Toronto: Methuen Publications, 1983); Roy Romanow, John Whyte and Howard Leeson, Canada ... Notwithstanding- The Making of the Constitution 1976-1982 (Canada: Carswell/Methuen, 1982) [Notwithstanding]; Robert Sheppard and Michael Valpy, The National Deal: The Fight for a Canadian Constitution (Toronto: Books, 1982) [The National Deal]; Edward McWhinney, Canada and the Constitution, 1979-1982: Patriation and the Charter of Rights (Toronto: University of Toronto Press, 1982) [Canada and the Constitution]; Ron Graham, The Last Act: Pierre Trudeau, the Gang of Eight, and the Fight for Canada (Canada: Penguin Canada, 2012) [The Last Act]; Patrick Monahan, Meech Lake: The Inside Story (Toronto: University of Toronto Press, 1991) [Inside Story]; Andrew Cohen, A Deal Undone: The Making and Breaking of the Meech Lake Accord (Vancouver: Douglas \& McIntyre, 1990) [Meech Lake Accord]; Kenneth McRoberts and Patrick Monahan (eds.), The Charlottetown Accord, the Referendum and the Future of Canada (Toronto: University of Toronto Press, 1993) [The Charlottetown Accord]; Peter H. Russell, Constitutional Odyssey: Can Canadians Become a Sovereign People?, $2^{\text {nd }}$ edition (Toronto: University of Toronto Press, 1993) [Odyssey]; and Jeremy Webber, Reimagining Canada: Language, Culture, Community, and the Canadian Constitution (Canada: McGill-Queens University Press, 1994) [Reimagining Canada].

${ }^{8}$ See, e.g., Lois Harder and Steven Patten (eds.), Patriation and Its Consequences: Constitution Making in Canada (Canada: UBC Press, 2015); Richard Albert, "The Difficulty of Constitutional Amendment in Canada", Alta. L. Rev., 53 (2015), 85-114; Richard Albert, “Constitutional Amendment by Stealth”, McGill L.J., 60:4 (2015), 673-736; Richard Albert, "The Conventions of Constitutional Amendment in Canada", O.H.L.J., 53 (2016, forthcoming) (addressing aspects of Canadian amendment constitutionalism); Kate Glover, "Structure, Substance \& Spirit: Lessons in Constitutional Architecture from the Senate Reform Reference", S.C.L.R., 67 (2 ${ }^{\text {nd }}$ edition) (2014), 221255; and Kate Glover, "Complexity and the Amending Formula", Constitutional Forum, 24:2 (2015), 9-16 (exploring the relationship between constitutional interpretation and constitutional amendment).
} 
While much of the literature on constitutional amendment is focused on textual rules and design variables, this article takes a different path. Before turning to the rhythms of Canada's amendment experience it offers a primer on the foundational concepts of legality and legitimacy, and their alignment in the constitutional setting. The analysis then addresses how those concepts have aligned over Canada's amendment history, before and after textual rules. The discussion takes its initial cue from the 1867 Constitution, which was incomplete as constitutional text for failing to include amendment rules. In default of rules, the Constitution was amended through a process of statutory legality which served, until 1982, as a proxy for constitutional legality, or textual amending rules. The legitimacy of amendment by UK legislative process was accepted, though more as a stopgap and with increasing discomfort after Canada's independence in $1931 .{ }^{9}$

The absence of rules had profound implications for Canadian constitutionalism and how the Constitution was perceived. Throughout this period Canada lacked amendment sovereignty because the Constitution could not amend itself. ${ }^{10}$ This gap in legality also presented acute legitimacy issues in a federal system of divided sovereignty between federal and provincial levels of government. In formal terms, the protracted search for amendment rules was about

\footnotetext{
${ }^{9}$ See W.R. Lederman, "The Process of Constitutional Amendment for Canada", McGill L.J., 12:4 (1966-67), 371-384 at 378 (stating that ["i]t is embarrassing for the British and humiliating for Canadians to maintain any longer these obsolete and incongruous formal steps of asking the British Parliament to act for us"); Jamie Cameron, "To Amend the Process of Amendment", in Gerald Beaudoin et al (eds.), Federalism for the Future: Essential Reforms (Montreal: Wilson \& Lafleur Ltée, 1998), pp. 319 (stating, years later, that it is questionable whether Canada was ever well served by a document that "robbed this country, from the outset, of the basic power to control its constitutional destiny").

${ }^{10}$ Again, the point is not that legal means for amending the text did not exist, because statutory legality served that function. Rather, the problem was that the Constitution did not provide rules for its constitutional amendment, or amendment according to the terms of the text (such as the division of powers between federal and provincial levels of government).
} 
legality and filling the textual gap, but more fundamentally required Canadian constitutionalism to define the terms and conditions of legitimate constitutional change.

As noted, patriation was transformative because that is when Canada acquired the authority to amend the Constitution domestically. ${ }^{11}$ The entrenchment of textual rules should have brought the legality and legitimacy of amendment into alignment, but that is not what happened. Despite ameliorating the omission of 1867, patriation could not close gaps in legitimacy that had spread from their roots in the rivalries of federalism to a fresh dynamic of rising democratic expectations. The urgency of those gaps led, in short years, to the two Accords, both which represent flagship moments of defeat in Canada's constitutional history. More poignant than the failure of legality in each instance was the virtual collapse of legitimacy, or democratic confidence in constitutional renewal. ${ }^{12}$ Despite a regime of constitutional legality which has been in place since 1982, that confidence has not been restored. As Canada approaches its sesquicentennial anniversary in 2017 there is lingering uncertainty on what is required to align the legitimacy of constitutional change with the current scheme of amendment legality.

The article's primary objective of theorizing legality and legitimacy in Canada's amendment history leaves little space for broader reflections on amendment theory and

\footnotetext{
${ }^{11}$ Canada Act, 1982, supra note 3, ss.38-49 (prescribing the rules for amendment which are referred to, collectively, as the amending formula). Note that some changes and amendments could be undertaken domestically prior to 1982; infra note 31 .

${ }^{12}$ The Accords failed on compound grounds of legality and legitimacy; the obstacles of legality might have been overcome had either or both Accords been able to muster sufficient legitimacy in the political community. See infra notes 74-77, 79, and 81 (citing scholarly analyses of the reasons the Accords failed).
} 
comparative constitutionalism. At a minimum, its symmetrical attention to these concepts - and constitutional legitimacy in particular - is distinctive in a literature that focuses on the text and how design variables affect amendment rigidity. ${ }^{13}$ As others have pointed out, by privileging the legality of amendment, textual singularity necessarily discounts the role of ambient political and constitutional culture as an agent of change. ${ }^{14}$ In providing an experiential analysis of Canada's amendment history this article exposes the limits of legality, engages legitimacy as a critical variable in constitutional change, and piques interest in how these concepts align in the setting of constitutional amendment.

\section{Legality, legitimacy and constitutionalism}

Law's authority derives from its legality and legitimacy, two concepts which can be but are not necessarily in harmony. Legality describes law's qualities by reference to the rules or requirements set out in formal or positive instruments, documents and enactments. Their terms may be complex, opaque or contested, but laws nonetheless prescribe the conditions and prerequisites to the exercise of authority. Of the two, legitimacy may be more elusive because it describes a law's quality or quotient of authoritative value. Though defined in variable terms, legitimacy is concerned with the status of a law or rule and whether its claim to regulate,

\footnotetext{
${ }^{13}$ Donald Lutz took the initiative in using quantitative models to study patterns of rigidity in constitutional amendment. See Donald Lutz, "Toward a Theory of Constitutional Amendment", Am. Pol. Sci. Rev., 88 (1994), 355370; Donald Lutz, Principles of Constitutional Design (New York: Cambridge University Press, 2006) [Principles]; see also Astrid Lorenz, "How to Measure Constitutional Rigidity: Four Concepts and Two Alternatives", J. Theoretical Politics, 17:3 (2005), 339-361.

${ }^{14}$ See, e.g., Xenophon Contiades, “Constitutional Change Engineering”, in Xenophon Contiades (ed.), Engineering Constitutional Change: A Comparative Perspective on Europe, Canada and the USA (Oxfordshire and New York: Routledge, 2013), pp. 1 (explaining that "[a]mending procedures dictate how constitutional change is supposed to take place [but] the reality of change is determined through the impact of other factors as well, such as the structure of the political system, the effect of civil or common law tradition, the system of judicial review and constitutional ethos").
} 
constrain, permit or prohibit is accepted by members of the community as a governing and binding obligation. Legitimacy generally attaches to the fact of legality because, in Weber's words, "the most common form of legitimacy is the belief in legality". ${ }^{15}$ Whether these concepts are aligned - what that means and how it is determined - is a major theme in legal and philosophical discourse.

The concern here is less with that discourse and more with how framework concepts apply to the making and amendment of constitutions. In principle, a written constitution expresses a conception of virtue in government that is intended to endure. The text articulates the legality of that conception, reflecting and incorporating fundamental beliefs and expectations about the powers and structures of government, and its relationship to a political community. As such, it embeds a conception of constitutional sovereignty, wrapping it in legitimacy and a hope or expectation of immortality. ${ }^{16}$

Weber's observation translates to the constitutional setting because a text which proclaims its status as the supreme law of the land will carry presumptive authority. Alignment questions can arise because legitimacy deficits may be present or may surface in a constitution's lifetime when there are gaps between the legality and authority of the text. To endure, a constitution fundamentally must "make sense to those who are under its dictates" and represent a

\footnotetext{
${ }^{15}$ Max Weber, Economy and Society: An Interpretive Sociology, Guenther Roth and Claus Wittich (ed.), Ephraim Fischoff, Hans Gerth, A.M. Henderson, Ferdinand Kolegar, C. Wright Mills, Talcott Parsons, Max Rheinstein, Guenther Roth, Edward Shils, and Claus Wittich (trans.), 2 vols. (Berkeley: University of California Press, 1978), pp. 37.

${ }^{16}$ Lutz, Principles, supra note 13, pp. 26-27 (stating that constitutionalism and the design of constitutions ultimately rest on the idea of sovereignty and that constitutionalism is one way of "organizing sovereignty").
} 
constitutional bargain that members of the community are invested in supporting. ${ }^{17}$ Legitimacy deficits are manifest in sham or camouflage constitutions, whose inauthentic texts purport to entrench rights or values that are a charade, disconnected from political reality. ${ }^{18}$ Constitutions also may exhibit congenital defects that undermine their legitimacy - or durability - and place them at risk of constitutional mortality. ${ }^{19}$ As well, a text may lack or lose authority where its prescriptions violate social, political or moral norms, or lack acceptance in segments of the community. ${ }^{20}$ The dynamics can also work in the other direction, though it is less problematic when a text presents a defect of legality but is accepted as legitimate, despite the flaw. ${ }^{21}$

Change is a vital part of durability, and how the text provides for amendment speaks, fundamentally, to what a constitution is. ${ }^{22}$ The terms and conditions of change must be prescribed with care because the legitimacy that attaches to constitution making is a requisite of change. Those rules negotiate difficult terrain, calibrating the balance between stability and

\footnotetext{
${ }^{17}$ Zachary Elkins, Tom Ginsburg and James Melton, The Endurance of National Constitutions (New York: Cambridge University Press, 2009), pp. 7 [Endurance].

${ }^{18}$ Richard Albert, "The Expressive Function of Constitutional Amendment Rules", McGill L.J., 59 (2013), 257-64 [“Expressive Function'\}.

${ }^{19}$ Elkins, Ginsburg and Melton, Endurance, supra note 17 (examining constitutional endurability and including case studies of congenital defects and constitutional mortality).

${ }^{20}$ This points to a defect of inclusion, which is an important element of endurance - or legitimacy - both at the moment of constitution making and over the life of a constitution. Ibid., pp. 78-81.

${ }^{21}$ Richard H. Fallon Jr., "Legitimacy and the Constitution”, Harv. L. Rev., 118:6 (2005), 1787-1853 at 1807 ["Legitimacy"] (citing the US Constitution as a case in point, and noting that although the prescribed ratification process was not legally legitimate, the Constitution's acceptance meant that it was sociologically legitimate).

${ }^{22}$ Albert, "Expressive Function”, supra note 18, 225-82 (explaining how and why amendment rules importantly express and protect a constitution's values). See also Richard Albert, "The Structure of Constitutional Amendment Rules”, Wake Forest L Rev., 49 (2014), 913-76 [“The Structure of Rules”], (providing a structural framework for understanding formal amendment rules and their effectiveness in balancing stability and flexibility).
} 
change, securing the moment of constitution making but providing for its durability by enabling it to evolve. The variables are almost limitless, with some constitutions inviting amendment and others discouraging it to forestall the risk of impulsive, improvident, and ill-advised spurts of reform. ${ }^{23}$ Whatever the design choice may be, amendment rules are an essential, foundational, and indispensable part of constitutional text. ${ }^{24}$ Those rules represent a form of legality which, in this article, is described as constitutional, amendment, or textual legality. ${ }^{25}$

Tension between a constitution's legality and legitimacy can arise when the text is out of step with shifts in legal, political and social culture. Pinpointing the moment of critical divergence between the two is challenging because legitimacy is perceptive in nature and operates at the level of belief. It is an organic part of constitutional culture that can be fluid, lacking in concreteness and nearly impossible to measure. In conceptual terms, legitimacy is theoretically divisible and can be analyzed from perspectives that include the legal, sociological and moral. ${ }^{26}$ Whatever the perspective, constitutional amendments must satisfy a standard of

\footnotetext{
${ }^{23}$ See Albert, "The Structure of Rules", ibid. (analyzing those variables and how they facilitate or constrain the amendment of constitutional text).

${ }^{24}$ Richard Albert, “Amending Constitutional Amendment Rules”, Int. J. Con. Law, 13 (2015), 655-85 (declaring, at 655 , that "[n]o part of a constitution is more important than the rules that govern its amendment" and adding that "[a]mendment rules are fundamental to constitutionalism").

${ }^{25}$ Amendment by informal or extra-textual means is also an important agent of constitutional change. See generally, Brannon P. Denning, "Means to Amend: Theories of Constitutional Change”, Tenn. L. Rev., 65 (1997), 155-244; David A. Strauss, "The Irrelevance of Constitutional Amendments", Harv. L. Rev., 114 (2002), 1457-1505; Brannon P. Denning and John Vile, "The Relevance of Constitutional Amendments: A Response to David Strauss", Tul. L. Rev., 77 (2002), 247-82.

${ }^{26}$ Fallon, "Legitimacy", supra note 21, 1790 (categorizing and analyzing three conceptions - the legal, sociological and moral - of a constitution's legitimacy and describing their relationship as "complexly interrelated").
} 
legitimacy, and that can be a tricky enterprise when the status quo is under review and the political community is asked to re-imagine foundational structures and promises. $^{27}$

Where amendment is concerned, constitutional legality and legitimacy are aligned, generally, when the text prescribes rules that enable change within a framework of durability that sufficiently represents and respects the values and choices of a political community. This should explain why it is anomalous for a written constitution not to include amendment rules and difficult to imagine how legality and legitimacy might align in such a system. In other words, amending a written text is bound to be problematic when there is no basis in legality to inform the legitimacy of change. Putting it in Weber's terms, a text without rules would require belief in a legality that does not exist.

In Canada's case, the Constitution's silence did not preclude textual change as amendments were achieved through a process of statutory legality. Despite its workability a subconstitutional process that could not be equated with constitutional legality led to shortfalls in the legitimacy of constitutional amendment over time. ${ }^{28}$ Amendment is a core function of constitutionalism and Canada's lack of amendment sovereignty had serious implications for the capacity and legitimacy of constitutional change, especially after independence. Moreover, the Constitution established a federal union, but the text's failure to provide rules formally excluded

\footnotetext{
${ }^{27}$ The American constitutional tradition attests that some of the most profound controversies about the legitimacy of change are provoked by judicial review and constitutional interpretation. See, e.g., Brown v. Bd. of Education, 347 US 483 (1954) (overruling separate but equal in public schools); Roe v. Wade, 410 US 113 (1973) (constitutionalizing a woman's right to seek an abortion).

${ }^{28}$ Although amendment by UK statutory legality was consistent with principles of Westminster and imperial constitutionalism, it was sub-constitutional in the meaning of this article because amendments were achieved by ordinary legislation rather than by the rules of a constitutional text.
} 
the provinces from the process of amendment. Without legality in the domain of federalism, the legitimacy of amendments affecting provincial sovereignty was unavoidably open to serious question. ${ }^{29}$ The lack of constitutional legality became progressively more incapacitating until the process of amendment was stopped prior to 1982, pending the adoption of rules.

The challenge deepened when a fresh legitimacy variable surfaced during negotiations on patriation. Though not a vital factor before 1982, the federal government's proposal for a referendum promoted democratic participation or popular sovereignty as an embryonic, or alternative way to legitimize transformative change. The rise of popular legitimacy affected both Accords which failed, in large part, because of a profound lack of confidence in constitutional renewal at multiple levels - from the process and substance of reform to complex synergies of federalism, regionalism, and democratic participation.

According to Fallon, the foundations of contemporary constitutional legitimacy "necessarily lie in current states of affairs" and are "more uncertain and contingent" than is assumed. ${ }^{30}$ While his conception examined its legal, sociological and moral varieties, the key variables at play in Canada's history of constitutional legitimacy concern elements of sovereignty: the sovereignty or authority to amend the Constitution, or amendment sovereignty; the sovereignty principles of federalism, including provincial sovereignty; and the role of popular sovereignty. Separately, in combination, and over time, these elements are the key to

\footnotetext{
${ }^{29}$ As Premier Allan Blakeney declared, "in a federal state, the procedure for amending the constitution is the most important part of the fundamental law; that I think is self-evident really". Quoted in Peter Oliver, "Canada, Quebec, and Constitutional Amendment”, U.T.L.J., 49 (1999), 519-60, 520 [“Canada, Quebec"].

${ }^{30}$ Fallon, "Legitimacy", supra note 21, 1852.
} 
Canada's history of constitutional amendment. From Confederation to the present, defining and aligning the legality and legitimacy of these sovereignties has been the primary burden of Canadian constitutionalism.

\section{Statutory legality: 1867 to 1982}

Alignment between the law and legitimacy of amendment is therefore a challenge, in principle, for a text that does not authorize change. For Canada the starting point is 1867 and a Constitution that failed to provide rules for its amendment. ${ }^{31}$ Whether it was a blunder or more an oversight at the time, the omission was costly and difficult to remedy. ${ }^{32}$ Statutory legality offered a workaround that bridged the textual gap and legitimized amendments to the Constitution between 1867 and 1931. There were diminishing returns to its legitimacy after independence, and by the 1960s the lack of rules had rendered the process functionally illegitimate: after 1964 the Constitution was not amended again until 1964. The dilemma throughout was this: while statutory legality was sub-constitutional, the lack of constitutional rules created a vacuum which complicated the task of developing a scheme of amendment legality that would be accepted as legitimate.

\footnotetext{
${ }^{31}$ Certain changes and amendments could be undertaken domestically prior to 1982 (i.e., altering "housekeeping" operations of the House of Commons and Senate, ss. 52, 40, 51, 35 and 18, and amending the constitutions of the provinces, s.92(1), the 1867 Constitution, supra note 2; admitting new provinces to the federation, The Constitution Act, 1871, 34- 35 Vict., c.28 (UK); and amending the Constitution of Canada, s.91(1), The British North America (No. 2) Act, 13 Geo. VI, c.81 (UK); Monahan and Shaw, Constitutional Law, supra note 3, pp. 168-73.

32 McWhinney describes it as a "major blunder" which "undoubtedly stemmed from the ignorance of British constitutional lawyers with the problems of written constitutions and the practical necessity of having amendment formulae built in"; Canada and the Constitution, supra note 7, pp. 65. Oliver, by contrast, suggests that it was "not likely to have been an oversight". "Canada, Quebec", supra note 29, 526-27.
} 
Confederation was an initiative of four colonies that expressed their "Desire to be federally united into One Dominion" under British authority, with a Constitution "Similar in Principle to that of the United Kingdom". ${ }^{33}$ UK legislation constituting Canada under those terms was legitimate because the colonies drafted the document and Britain gave it legal force by enacting the BNA Act. ${ }^{34}$ The legalities at the time were two-fold: Dominion status described and determined the relationship between Canada and the United Kingdom, and the Constitution established the terms of federal union between the partners to Confederation. ${ }^{35}$ As a Dominion, Canada was self-governing but was subject to forms of imperial oversight, including Britain's power to disallow federal legislation and judicial review of domestic legislation by the Judicial Committee of the Privy Council. ${ }^{36}$ Amending the 1867 Constitution was another area in which Canada lacked sovereign authority, because the Colonial Laws Validity Act prohibited domestic legislation that was in conflict with applicable imperial legislation. ${ }^{37}$ The BNA Act was such a statute and could only be amended by the UK legislature.

In origin, statutory legality was a function of imperial hierarchy and parliamentary sovereignty, having little to do with constitutional legality or legitimacy. Yet in practice, Dominion status meant that the British Parliament would respect Canada's autonomy on matters

\footnotetext{
${ }^{33}$ BNA Act, supra note 2, preamble.

${ }^{34}$ The four confederating colonies were Upper and Lower Canada - present day Ontario and Quebec - along with Nova Scotia and New Brunswick.

${ }^{35}$ BNA Act, supra note 2, ss.91, 92 (defining the primary division of powers between the federal and provincial governments).

${ }^{36}$ BNA Act, ibid., s. 56. The Judicial Committee of the Privy Council ("JCPC") served as Canada final court of appeal until 1949, when the Supreme Court of Canada was empowered by federal legislation to assume that role; Act to Amend the Supreme Court Act, S.C. 1949 ( $2^{\text {nd }}$ sess.), c.37.

${ }^{37} 28-29$ Vict. c.63 (1865) (U.K.) (“CLVA”).
} 
of domestic governance. The UK never exercised its disallowance power or amended the Constitution without Canada's consent, as it was legally entitled to do, and soon after Confederation the UK agreed to act on the federal government's requests for amendments to the BNA Act. ${ }^{38}$ In this way, Britain fettered its legal power through a convention accepting Canada's authority to determine when and how the BNA Act would be amended. ${ }^{39}$

Because it was concerned with the relationship between imperial authority and a selfgoverning Dominion the UK convention treated the federal government as the legitimate source of authority on amendment. The convention was political rather than legal in nature and did not contemplate substantive review to ensure that proposed amendments complied with the Constitution. ${ }^{40}$ An interesting parallel is revealed in the chain of legality, from the UK to the federal government, and the federal government to the provinces: just as the federal government had no legal power to prevent the UK from amending the Constitution, the lack of textual rules meant that the provinces had no authority to prevent unilateral amendment by the federal government. While the UK amendment convention accepted that Britain could not exercise its legal powers without undercutting Canada's constitutional autonomy, there was no parallel recognition that unilateral federal amendment could undermine the sovereignty of the provinces.

\footnotetext{
${ }^{38}$ The convention began to crystallize before or at the time of Confederation. Monahan and Shaw, supra note 3, pp. 174.

${ }^{39}$ The UK convention was complemented by a local convention requiring a resolution of the Canadian Parliament to activate the process of constitutional amendment. This convention simply complied with the norms of parliamentary government, including the principles of responsible government. Ibid., pp. 175-76.

${ }^{40}$ P. Gérin-Lajoie, Constitutional Amendment in Canada (Toronto: University of Toronto Press, 1951), pp. 217 (stating that the "most common view today [i.e., 1951] is ... that British action would be automatic upon a request from the Canadian Houses of Parliament"). Note that it was unclear in 1981 whether the UK Parliament would grant the federal government's request for unilateral amendment and patriation of the Constitution. Infra note 66.
} 
Amendments effected through a binary process between the UK and federal government could work in a unitary state or federal system that subordinated the provincial level of government, but that was decidedly not the way Canadian federalism evolved. The prevalent view that Canada's federal union was hierarchical in conception was offset, from the outset, by a strong counter vision. ${ }^{41}$ Moreover, in the years after 1867, a robust tradition of judicial review developed to protect the constitutional division of powers. Shaping Canadian federalism by enhancing and entrenching provincial autonomy is one of the hallmarks of the Privy Council's constitutional jurisprudence, which granted the provinces co-equal status in their areas of exclusive constitutional jurisdiction under $\mathrm{s} .92 .{ }^{42}$ Outside the constitutional domain, the dynamics of federalism continued to shift as Confederation expanded and the provinces matured, gaining economic and political power.

The BNA Act left the provinces powerless and without a voice on constitutional reform. Though amendments were infrequent in the early years of Confederation, the provinces began to resist the assumption that the amendment function was controlled by the federal government. ${ }^{43}$

\footnotetext{
${ }^{41}$ BNA Act, supra note 2; For textual indices of the federal government's dominant role see, e.g., s. 90 (granting the federal government the power to disallow provincial legislation); ss.91-92 (textualizing federal paramountcy); and ss. 55-57 and 58 (providing that the federal government would appoint the lieutenant governors of the provinces and could instruct them to withhold consent to provincial bills or to reserve them for the federal government's consideration).

${ }^{42}$ See, e.g., Hodge v. The Queen (1883) 9 App. Cas. 117 at 132; Dom. Sess. Pap. 1884, Vol. 17, No. 30 (pronouncing that within the scope of s.92, the provinces are "supreme" and have "authority as plenary and ample" as the Imperial Parliament or the Parliament of the Dominion).

${ }^{43}$ Monahan and Shaw, supra note 3, pp. 176. Provincial opposition to a proposed constitutional amendment was registered for the first time in 1907, with British Columbia's objection to a new scheme for financial subsidies under s.118 of the BNA Act. The amendment went ahead with the support of eight of nine provinces.
} 
Even so, a domestic convention to validate their role and constrain the federal government from acting unilaterally was slow to evolve. When Canada became independent in 1931, there was no established practice of consulting with provinces or obtaining their consent to proposed amendments, much less a crystallized convention binding the federal government to do so. ${ }^{44}$ The legitimacy of that claim was acknowledged, importantly and for the first time, by the Statute of Westminster.

1931 was a transformative year for the British Dominions that gained independence under the Statute of Westminster and also for the UK, which had to reconcile a surrender of power with parliamentary and imperial sovereignty. ${ }^{45}$ This statute was unprecedented in the history of the Empire because it provided for its self-governing Dominions to attain independence and released them from the terms of the Colonial Laws Validity Act, including its principle of repugnance. ${ }^{46}$ Section 4 stated that British law would no longer apply to the Dominions, except at their request and with their consent. ${ }^{47}$ Force of circumstance led Canada to make an exceptional request.

\footnotetext{
${ }^{44}$ At the time of independence there was little or no evidence of such a convention, which remained unclear up to patriation, and was grounded in four amendments in 1940, 1951, 1960, and 1964. Infra note 57.

${ }^{45}$ 1931, 22-23 Geo. 5, c.4, s.7 (UK).

${ }^{46}$ Ibid., s.1 (defining "Dominions" to include the Dominion of Canada, Commonwealth of Australia, Dominion of New Zealand, Union of South Africa, Irish Free State, and Newfoundland) and s.2(2) (negating the principle of repugnance).

${ }^{47}$ Ibid., s.4 (stating: "No Act of Parliament of the United Kingdom passed after the commencement of this Act shall extend, or be deemed to extend, to a Dominion as part of the law of that Dominion, unless it is expressly declared in that Act that that Dominion has requested, and consented to, the enactment thereof").
} 
For Canada, independence would bring UK statutory legality to an end and create a new void that would enable either level of domestic government to alter the Constitution by ordinary legislation. ${ }^{48}$ As a result, the Constitution might be more at risk of unilateral and unconstitutional amendments after independence than under the imperial regime of UK statutory legality. Even though the UK was bound to grant the federal government's amendment requests, the convention was protective in a way, because the British Parliament retained the legal authority to grant or deny such requests. ${ }^{49}$

In anticipation of independence, the federal government and provinces unsuccessfully attempted to agree on amendment rules in 1927 and again in $1931 .^{50}$ That created a predicament which presented Canada with an unsavoury choice between postponing independence until rules could be drawn, and accepting independence but preserving British authority over the Constitution. If neither was desirable, a constitutional exception was still more attractive than deferring independence. In response to the provinces' concerns, the federal government asked the BNA Act to be exempted from the Statute of Westminster, and Canada's independence was

\footnotetext{
${ }^{48}$ Peter Hogg, "A Comment on the Canadian Constitutional Crisis", Yale Studies in World Public Order, 6 (1980), 285-296 at 286, 289 [“Constitutional Crisis”], (citing this risk).

${ }^{49}$ See Oliver, "Canada, Quebec", supra note 29, 526-27 (discussing the historical purpose of amendment by the UK and stating, in note 35, that "the Imperial Parliament could be at once a means of remedying any defect in the new Constitution and a force of stability and reason"); see also infra note 66.

50 James Ross Hurley, Amending Canada's Constitution: History, Processes, Problems and Prospects (Canada: Minister of Supply and Services Canada, 1996), pp. 25-7 [Amending Canada's Constitution].
} 
accompanied by a statutory asterisk preserving its dependence on the UK for amendments to the Constitution. $^{51}$

By out-sourcing textual amendments to a foreign sovereign after independence, Canada accepted a stunning and unusual limit on its authority. It is overlooked, because not described as such, that Westminster's BNA Act exceptionalism was formally and in functional terms an amending formula. ${ }^{52}$ As a formula it was dysfunctional, because it continued the status quo of statutory legality and retained the trappings of colonial subservience. Despite the irregularity, the Westminster amending formula had legitimacy because it created a form of legality that prevented self-interested parties to Canada's federal union from undercutting constitutional promises through ordinary statutory actions. ${ }^{53}$ More to the point, s.7's BNA Act exception codified the principle - by agreement of the federal government and provinces - that constitutional legality was necessary to legitimize amendments to the Constitution. ${ }^{54}$ Until that could be achieved, the imperial monitor would remain in place to protect the integrity of Canadian federalism. In this way, the status quo served as a placeholder on amendment which

\footnotetext{
${ }^{51}$ Supra note 45. Section 7(1) states: "Nothing in this Act [i.e., granting independence] shall be deemed to apply to the repeal, amendment or alteration of the British North America Acts, 1867 to 1930, or any order, rule or regulation made thereunder".

52 See Oliver, "Canada, Quebec", supra note 29, 573 (observing that Canada chose to retain the legislature of another country as its "ultimate amendment procedure" and that the Westminster Parliament was "simply an amending formula").

${ }^{53}$ See Fallon, "Legitimacy", supra note 21, 1809 (describing "minimal" legitimacy and suggesting that officials and citizens might accept a duty to support "even flawed legal regimes" in the absence of a better alternative).

${ }^{54}$ Russell, Odyssey, supra note 7, pp. 55 (commenting, in relation to the 1927 meeting that, "[t]he fact that the federal government would not act on ... Canada's constitutional sovereignty without full consultation with the provinces shows that the Government of Canada did not feel it had full authority to speak for ... Canadians" and that the provincial governments were "accepted as essential constituent elements of the 'autonomous community'".
} 
recognized the stake of the provinces, in the era of Canadian independence, in the process and substance of constitutional amendment. Whatever might be said of placing faith in an amendment protocol which had excluded the provinces for more than 60 years, this development was symbolically important and marked an important evolution in Canadian federalism.

In the circumstances, preserving British oversight of a vital constitutional function should have provided incentive for Canada's two levels of government to negotiate an amending formula. Instead, it signalled deepening distrust between the parties to federalism and foreshadowed years of stalemate. Prolonged dependence on UK statutory legality may have seemed innocuous but had the effect, over the next five decades, of incapacitating and disabling the amendment function.

The federal government and provinces were unable to agree on an amending formula over the course of fourteen high-level meetings between 1931 and $1982 .{ }^{55}$ Success was complicated by the dual nature of the task: as a matter of legality, the parties had to accept constitutional amendment rules but additionally decide how much agreement was necessary to legitimize those rules. Agreement was achieved in 1964 and again in 1971, though both amending formulas stalled when unanimity faltered. ${ }^{56}$ In the absence of any standard of legality,

\footnotetext{
${ }^{55}$ Hurley, Amending Canada's Constitution, supra note 50, pp. 22-63 (documenting this history).

${ }^{56}$ Monahan and Shaw, supra note 3, pp. 179-80. Whereas the 1964 Fulton-Favreau formula required unanimous consent for all amendments affecting the division of powers, the 1971 Victoria Charter was based on agreement by the federal government, Ontario, Quebec, and a majority of the western and Atlantic provinces. Quebec alone withdrew its support from the Fulton-Favreau proposal, and Saskatchewan and Alberta joined Quebec in withdrawing from the Victoria Charter after provincial elections, because Ontario and Quebec were the only provinces to receive a veto.
} 
either the Fulton-Favreau formula or Victoria Charter could have proceeded on the basis that sufficient agreement had been reached. Tellingly, it was assumed instead that legitimacy required the agreement of all parties or at least of Quebec.

Meantime, the Westminster amending formula remained in place and the Constitution was amended nine times between 1931 and 1982. Provincial consent was sought and obtained for three amendments in this period that directly affected s.92 interests, but not on other occasions when the federal government maintained that their interests were not at stake. ${ }^{57}$ Even as the status of a convention remained uncertain the legitimacy of unilateral federal amendment diminished. ${ }^{58}$ Longstanding negotiations made the claim of a formal role for provinces compelling, if not legally or politically binding on the federal government. The federal government unilaterally amended the Constitution for the last time in 1949, and no amendments were advanced between 1964 and 1982.

\footnotetext{
${ }^{57}$ Ibid., pp. 170-73, pp. 176-79. Four amendments were preceded by unanimous provincial consent (i.e., unemployment insurance, 1940; old-age pensions, 1951; judicial tenure of office, 1960; and old-age benefits, 1964). Others proceeded without provincial consent or over provincial objection (i.e., postponing the redistribution of House of Commons seats, 1943; adjusting the formula for House of Commons representation, 1946; enabling the federal government to amend the Constitution and admitting Newfoundland to Confederation, 1949). The 1949 amendment authorizing the federal government to amend the Constitution was particularly contentious; while the federal government insisted on the exclusive authority to make certain amendments to the Constitution, Quebec and six provinces demanded that the amendment be repealed. Oliver, "Canada, Quebec", supra note 29, 535 .

${ }^{58}$ The influential Favreau White Paper on constitutional amendment hedged the question of provincial consent, stating that "[t]he nature and degree of provincial participation in the amending process ... have not lent themselves to easy definition". G. Favreau, The Amendment of the Constitution of Canada (Ottawa: Queen's Printer, 1965), pp.15; see also Hogg, "Constitutional Crisis", supra note 48, 286 (discussing the status of such a convention and concluding, in 1980, that "[w]hether a convention requiring provincial consents to altering the distribution of powers has become established practice is not entirely clear").
} 
Desperately unsuccessful negotiations would bring Canada to the brink in 1981. Events had demonstrated that the legality and legitimacy of constitutional amendment simply could not be aligned. As a matter of formal legality, Canada's Constitution could still be amended by a foreign sovereign, acting at the request of a federal government that chose to disregard the terms of the Constitution and interests of the provinces. Amendments undertaken through that process would heighten misalignment between the two by satisfying the requirements of legality but in doing so manifestly lacking legitimacy.

\section{Constitutional legality: patriation and the Accords}

Short of unanimity, a scheme of amendment legality that would satisfy the provinces could not be found. In due course, fault for the amendment impasse would be attributed to the politicians who, "despite intermittent efforts since 1927 and very intensive efforts since 1968", were unwilling to set aside jealousies and differences to work together on domestic amendment rules. ${ }^{59}$ By the 1970 s, a self-reinforcing history of failed negotiations was aggravated by the rise of militance among the provinces. ${ }^{60}$ The collapse of negotiations yet again, shortly after Quebec's May 1980 referendum on sovereignty-association, enabled Prime Minister Trudeau to claim the "political high ground" for unilateralism when he introduced the federal government's

\footnotetext{
${ }^{59}$ Hogg, "Constitutional Crisis", ibid., 286. Frustration is also evident in remarks by Pierre Trudeau, who commented on "what enormous amounts of bile and wasted time constitutional conferences had produced ... only to discover how impossible it was to get [the first ministers] to agree on a constitutional amending formula"; quoted in Graham, The Last Act, supra note 7, 15.

${ }^{60}$ McWhinney, Canada and the Constitution, supra note 7, 4 (describing a "pan-Canadian confrontation in which all the provinces seemed to be joining together to make a common war against the federal government").
} 
unilateral patriation plan. $^{61}$ That plan was designed to unblock constitutional reform by challenging the provinces and the tyranny of unanimity. ${ }^{62}$

This act of constitutional derring-do willed a breakthrough on patriation by joining the federal government's authority to request amendments with a legitimizing referendum on the amending formula. ${ }^{63}$ The referendum option not only gave the federal government leverage against the provinces but deflected their sovereignty in favour of two other sources of legitimacy: the federal government's legitimacy to act on its legal authority, as representative of the Canadian people; and the democratic authority of an inclusive, nationwide referendum. Though patriation was achieved without a referendum, the appeal to direct democracy and the "people's constitution or people's package," as the proposal was styled, fundamentally altered the dynamics of constitutional reform. From that point on, popular legitimacy played an increasingly important role in shaping and determining the success or failure of constitutional reform.

\footnotetext{
${ }^{61}$ Graham, The Last Act, supra note 7, pp. 68. The key elements of the plan were an amending formula, which would serve to patriate the Constitution, and a charter of rights. Also note for clarity that all references in this article are to Prime Minister Pierre Elliot Trudeau and not to the current Prime Minister, his son Justin Trudeau.

${ }^{62}$ As Prime Minister Trudeau complained, "we took the idea of unanimity and made it a tyrant .... We were led by the dictates of unanimity to bargain freedom against fish, fundamental rights against oil, the independence of our country against long-distance telephone rates". Graham, ibid, pp. 68.

${ }^{63}$ According to the proposal, the federal government and provinces would have two years to achieve unanimity on an an amending formula, in default of which the provinces could propose an amending formula. That formula, along with the Victoria Charter, would be submitted in a referendum to the electorate within four years of patriation. Should the provinces fail to advance a formula, then the Victoria rules would come into effect within two years of patriation, without a referendum. McWhinney, Canada and the Constitution, supra note 7, pp. 53-54.
} 
Eight of the ten provinces opposed patriation by taking the federal government, and once the Supreme Court of Canada confusingly decreed that unilateral patriation was both legal and unconstitutional their role could no longer be circumvented. ${ }^{64}$ By endorsing its legality but rejecting the legitimacy of the federal proposal a splintered Court wittingly or unwittingly played a vital role in brokering the patriation deal. ${ }^{65}$ The Patriation Reference's judicial draw between unilateral patriation's legal and constitutional status forced another round of negotiations, in particular because the federal government could not predict how the UK might respond. ${ }^{66}$ Again it pressed a referendum option as a strategy for bargaining against the sovereignty claims of the provinces. $^{67}$ Not surprisingly, but with one critical exception, the provinces were uniformly opposed to a proposal that would deflect and diminish their importance in the process of

${ }^{64}$ Re Resolution to Amend the Constitution [1981] 1 SCR 753, 11 Man R (2d) 1 [the "Patriation Reference"]. Seven of nine judges agreed that the federal government had the legal power to proceed unilaterally, with two dissenting strongly to defend the integrity of Canadian federalism. A differently constituted majority of six judges then found that the patriation plan was unconstitutional because it violated a domestic constitutional convention that required an indeterminate but "substantial" level of provincial agreement. Three judges dissented strongly on the ground that such a constraint was unprecedented and unrecognized in constitutional law.

65 For a recent comment, see Philip Girard, "Law, Politics, and the Patriation Reference of 1981", in Harder and Patten, Patriation and its Consequences, supra note 8, pp. 115-36.

${ }^{66}$ A key question throughout was whether the UK Parliament would act on the federal government's request for unilateral constitutional amendments. By then the UK had been approached and extensively lobbied in an attempt to persuade Parliament that convention did not require it to accede to the Canadian government's requests in all cases, and especially where the patriation package fundamentally lacked domestic legitimacy. Whether the UK might depart from the established protocol of statutory legality in response to such a serious legitimacy shortfall was part of the intrigue that compelled the federal government to resolve its differences with the provinces. See Romanow, Whyte and Leeson, Notwithstanding, supra note 7, Chapter 5, "The Battle of Britain", pp. 134-54; McWhinney, Canada and the Constitution, supra note 7, Chapter 7, “Cutting the Gordian knot", pp. 65-71.

${ }^{67}$ Over the course of negotiations from November 2-5, 1981, the proposal for a referendum took many forms and was broadened to include a vote on patriation and the Charter of Rights and Freedoms, as well as the rules for amendment. For an account, see Romanow, Whyte and Leeson, Notwithstanding, supra note 7, Chapter 7, "The Week That Was", pp. 188-215. 
amendment. ${ }^{68}$ Agreement on patriation without democratic participation was reached when the federal government abandoned a referendum in exchange for consent from all provinces but Quebec. ${ }^{69}$ As a matter of political calculation, the rest-of-Canada leadership concluded that the patriation package was legitimate enough because the Court was unwilling to endorse a constitutional requirement of unanimity. ${ }^{70}$ Despite satisfying the Court's standards of legality and legitimacy, the patriation plan provoked resistance, not only in Quebec but from powerful rights-seeking members of Canada's democratic community. ${ }^{71}$

Patriation came in 1982 at high cost: Quebec was dealt an unforgivable insult that largely robbed patriation of legitimacy in that province and radically escalated the danger of separation. $^{72}$ Quebec's exclusion and the gaping legitimacy deficit it caused set off a chain

\footnotetext{
${ }^{68}$ All provinces, except Quebec - in a moment of unguarded weakness - were opposed because a referendum would fundamentally re-focus the source of legitimacy for change on the democratic community, through a process managed by the federal government.

${ }^{69}$ Quebec's exclusion from the Kitchen Accord, in the so-called "night of the long knives," is a legendary part of the patriation saga and the catalyst for the Meech Lake Accord. See generally Graham, The Last Act, supra note 7, Chapter 14 ("The Kitchen Accord"), pp. 190-98, and Chapter 15 (“The Night of the Long Knives"), pp. 201-11.

${ }^{70}$ On the question of constitutionality, the Court held that a substantial degree of provincial consent was required and stated also that "[n]othing more should be said about this". Patriation Reference, supra note 64 at 905 . The important element there was that the Court had stated that the rule of unanimity "under which past constitutional conferences labored and ultimately failed" was not a conventional - or constitutional - requirement. Romanow, Whyte and Leeson, Notwithstanding, supra note 7, pp. 188.

${ }^{71}$ After the re-negotiated plan was announced the "unexpected" occurred, with the genuine involvement of the general public in a "seemingly quite spontaneous and at first quite unco-ordinated public reaction, which was communicated directly and pressingly to the premiers and their supporters"; McWhinney, Canada and the Constitution, supra note 7, pp. 102. See also Sheppard and Valpy, The National Deal, supra note 7, pp. 307 (stating that in the face of intense pressure, especially on women's and aboriginal rights, the provincial governments "folded like omelettes").

72 Even before formal enactment on April 17, 1982 Quebec contested the constitutionality of patriation, claiming a veto over constitutional amendment, which was rejected by the Supreme Court of Canada; Re: Objection by Quebec to a Resolution to Amend the Constitution, [1982] 2 S.C.R. 793, 140 DLR (3d) 385; The province also
} 
reaction that further imperilled the fragile status of constitutional reform and threatened the Constitution's durability as a nation. On its face, the Meech Lake Accord ("MLA") was a wellintentioned reform initiative aimed at completing patriation by healing the wounds of 1982 through a "Quebec Round" redressing the province's grievances. ${ }^{73}$ Unanimous agreement at the level of executive federalism anchored the Accord's legitimacy, gestured in humility toward amend-making with Quebec, and at least initially augured well for the MLA's acceptance.

By courting Quebec's agenda, entertaining asymmetric arrangements, and privileging Quebec as a distinct society, the MLA ignored pent-up demands and expectations for movement on women's and aboriginal rights, as well as Senate Reform. ${ }^{74}$ Over the three-year ratification period from 1987 to 1990, the legitimacy of prioritizing Quebec and in the meantime sidelining other issues steadily declined. ${ }^{75}$ Process deficits were a further and important aggravation: the MLA process was closed, lacking in transparency, and non-inclusive; it shut out newly

\footnotetext{
enacted legislation overriding the Charter across the spectrum of provincial statute law; An Act respecting the Constitution Act, 1982, S.Q. 1982, c. 21.

${ }^{73}$ The MLA proposed amendments that recognized Quebec as a distinct society; required the federal government to grant provinces a greater role in immigration and to select Supreme Court of Canada judges from lists of names from the provinces; entrenched Quebec's right to three judges on the Court; and allowed the provinces to opt out of share cost programs, under certain conditions; and granted all provinces a veto on s.42 amendments. See Monahan, Inside Story, supra note 7, pp. 297-305 (Appendix 3, text of the MLA), pp. 306-14 (Appendix 4, 1990 Constitutional Agreement).

${ }^{74}$ Romanow, Whyte and Leeson, Notwithstanding, supra note 7, pp. 276-78 (stating that "the need for constitutional reform has not been lessened by the limited success of 1982" and pointing to unresolved constitutional dilemmas like Quebec, aboriginal peoples, the Senate, the Supreme Court of Canada, and economic union).

${ }^{75}$ See Monahan, Inside Story, supra note 7 (analyzing the full history of the MLA and explaining Premier Bourassa's crucial decision to invoke the override to protect Quebec's language legislation from Charter review as a turning point in the saga, because it alienated Canadians outside Quebec and raised deep concerns about the constitutionalization of a "distinct society" clause for Quebec).
} 
empowered voices that had the resources, political will and visibility to confront the bygone legitimacy of executive federalism. Three years after its announcement was celebrated the Accord failed for want of ratification on June 23, 1990. Unanimity was required as a matter of legality and the Manitoba and Newfoundland legislatures refused to ratify the MLA at the last minute.

Accounts of the Accord's failure abound, and include attention to the obstacles arising from the legalities of amendment, which set a three-year time period and required all provincial legislatures and the federal government to ratify the agreement. ${ }^{76}$ More telling than legality's obstacles were the MLA's legitimacy defects and miscalculations. ${ }^{77}$ As one observer commented, "the Constitution [was] no longer an affair of governments" and not only had federalism "lost status in the Constitution as an organizing principle", there was outrage at the “illegitimacy of governments perceived as playing fast and loose with a Constitution which they had forgotten was no longer theirs alone". ${ }^{78}$

\footnotetext{
${ }^{76}$ See, e.g., Monahan, ibid.; Cohen, Meech Lake Accord, supra note 7 (pointing to the fundamental disconnect in the process between the political leadership and the electorate); Katherine Swinton, "Amending the Canadian Constitution: Lessons from Meech Lake”, U.T.L.J., 42 (1992), 139-169 at 144 ["Lessons from Meech Lake”] (pointing to changes in political will and provincial elections in New Brunswick, Manitoba and Newfoundland, which affected the MLA).

${ }^{77}$ Webber, Reimagining Canada, supra note 7, pp. 134-62 (explaining that "there was no coherent description of the whole, no explanation why Meech Lake made sense in terms of Canada" and it was "inevitably seen as a crass trade-off, extracted by threats from Quebec, contrary to constitutional principle"; ibid., 162).

${ }^{78}$ Alan C. Cairns, "The Limited Vision Constitutional Vision of Meech Lake", in K.E. Swinton and C.J. Rogerson, (eds.), Competing Constitutional Visions: The Meech Lake Accord (Canada: Carswell Co. Ltd., 1988), pp. 259, 261 and 256 .
} 
In a climate of escalating anxiety over Canada's future, Meech Lake's defeat simply make the next initiative inevitable. Quebec issued an ultimatum that brought urgency to the task of accommodating its minimum demands for constitutional amendments without repeating the mistakes of the MLA. ${ }^{79}$ The "Canada Round" was the result of an expedited but nationally inclusive process of democratic renewal which proposed constitutional reforms across a range of institutional and substantive constitutional issues. ${ }^{80}$ Addressing the substantive and procedural deficits of the MLA backfired, however, because the Accord's unwieldy reforms did not register as authentic in the democratic domain. Proposals which were inevitably and unavoidably dilute sounded in political expedience and inspired more antagonism than generosity. ${ }^{81}$ Following an intense campaign the Accord was defeated in a national referendum held on October 26, 1992, which conclusively rejected the proposal. ${ }^{82}$ Paradoxically, while the MLA failed because it was under-inclusive, the Charlottetown Accord was over-inclusive to a fault. ${ }^{83}$

\footnotetext{
${ }^{79}$ Quebec announced that with or without a constitutional overture from the rest of Canada there would be a referendum on separation no later than October 26, 1992.

${ }^{80}$ After reports, negotiations and a nationwide Renewal of Canada campaign, the federal government and provinces unanimously agreed, once again, to transformative constitutional change. See, e.g., The Process for Amending the Constitution: The Report of the Special Joint Committee of the Senate and the House of Commons (Canada: Queen's Printer, 1991) (the "Beaudoin-Edwards Report"); The Citizen's Forum on National Unity (the "Spicer Report") (Canada: Queen's Printer, 1991); and Report of the Special Joint Committee on a Renewed Canada (Canada: Queen's Printer, 1992) (the Beaudoin-Dobbie Report"). See also Monahan and McRoberts, The Charlottetown Accord, supra note 7,pp. 278-309 (Appendix 1, "Consensus Report on the Constitution", Final Text, August 28, 1992).

${ }^{81}$ See Webber, Reimagining Canada, supra note 7, pp. 174-75 (reflecting on the reasons for the Accord's failure and remarking on "a continued inability to resolve the basic tensions left over from Meech" and describing Charlottetown as "a set of largely ad hoc trade-off, unsupported by a vision of the country as a whole"; Ibid., 175).

${ }^{82}$ The Accord passed muster in four of ten provinces, and was defeated, as a matter of popular vote, by a margin of 54.3\% against and 45.7\% in favour; Monahan and McRoberts, The Charolottetown Accord, supra note 7, Appendix 3, "Official Voting Results, by Province".

${ }^{83}$ See, e.g., Monahan and McRoberts, ibid. (presenting articles by a number of leaders discussing what was wrong, in process and substance, with the Charlottetown Accord); see also Matthew Mendelsohn, "Public Brokerage:
} 
Each of the post-textual initiatives set a high threshold for the legality of constitutional reform. Each time the proposals for changes were mis-aligned in important ways with preexisting and developing expectations of what legitimizes constitutional change. Constitutional reform cannot be attempted again, with any realistic prospect of success, until that lingering misalignment is overcome. In response to the failure of reform, Part V's constitutional legality has been embossed by statutory legalities, both federal and provincial, which layer and further confound the process of constitutional amendment. In part these requirements revolve around Quebec and its status in Confederation, but also respond to the dynamics of legitimacy in the rest of Canada. $^{84}$

It is clear, from the nature and scale of these supplements, that Part V's amendment legality is not sufficient to legitimize constitutional change. Not only is the co-existence and overlap of constitutional and extra-textual regimes of legality confusing, it raises perplexing

Constitutional Reform and the Accommodation of Mass Politics" Can. J. of Poli. Sci., 33:2 (2000), 245-272 ["Constitutional Reform"] (explaining that the 1992 Accord failed because compromises were forged at the elite level but ratification was sought and required at the mass level).

${ }^{84}$ See, e.g., An Act representing constitutional amendments, S.C. 1996, c.1 [Regional Veto Act] (prohibiting constitutional amendments from being proposed unless certain provinces have consented, namely Ontario; Quebec; British Columbia; at least two Atlantic provinces representing at least $50 \%$ of the population; and at least two of the three prairie provinces having at least $50 \%$ of the population). At the provincial level, Alberta and British Columbia require a binding referendum before their legislatures can approve constitutional amendments; see Constitutional Referendum Act, R.S.A. 2000, c. C-25; Constitutional Amendment Approval Act, R.S.B.C. 1996, c.67. Saskatchewan also has referendum legislation but does not require or contemplate a referendum as an imperative; Referendum and Plebiscite Act, S.S. 1990-91, c.R-8.01. It is now widely believed that legitimacy demands a national referendum to validate Part $V$ amendments to the Constitution. See also Supreme Court of Canada decisions: the Reference re Secession of Quebec, [1998] 2 S.C.R. 217, [1998] S.C.J. No 61 (and the Clarity Act, S.C. 2000, c.26); Reference re Supreme Court Act ss.5 and 6, 2014 SCC 21, [2014] 1 S.C.R. 433 and Reference re Senate Reform 2014 SCC 32, [2014] 1 S.C.R. 704 (placing judge-made caveats and qualifications on the substance and process of constitutional amendment). 
questions about the constitutional text. ${ }^{85}$ The most critical of these asks why constitutional legality, achieved in 1982 after so long and at such expense, is not enough. Moreover, instead of clarifying amendment legality, these extra- or super-textual requirements point to ongoing tension about the source of legitimacy for change. It remains uncertain, in this bewildering array of rules, whether the legitimacy of constitutional change depends, fundamentally, on sovereignty principles of federalism, on a concept of regional sovereignty, which includes; on the popular sovereignty of Canada's democratic community; or on the sovereignty interests of its people, including aboriginal communities. Though all elements are represented in the current melange, their relationships and the relationship between statutory and constitutional requirements are muddled.

In the aftermath of failed reform, the amendment process was "deeply dysfunctional" because managing concurring and competing legitimacies spun out of control and created a "widespread sense of powerlessness" and a perception that constitutional change had been rendered impossible. ${ }^{86}$ Time has not substantially altered that assessment, and though it is open to serious doubt that adding layers of legality will boost the legitimacy of constitutional reform, the issue may be academic. Canada's Constitution has become among the most rigid and most

\footnotetext{
${ }^{85}$ Extra-textual constraints aimed at enhancing the legitimacy of amendment complicate and obscure the process, and delegitimize the textual rules for change. See Albert, "Formal Amendment Difficulty", supra note 33 at 17-18 (draft) (explaining that these extra-textual restrictions are harmful for the rule of law because they "breed doubt" about the text itself, effectively amend Part V's rules, and in doing so, compound the rigidity and uncertainty of constitutional amendment's requirements). Possible solutions include returning to and treating Part $V$ as a complete code for constitutional change, or amending Part $V$ to include a referendum process in the legality of amendment. Such a requirement might not make reform more likely to succeed, but would address a perceived legitimacy gap and create textual certainty around what is required for constitutional renewal.

${ }^{86}$ Mendelsohn, “Constitutional Reform”, supra note 83, 272.
} 
difficult to amend in the world. ${ }^{87}$ There is little doubt that reform cannot realistically be initiated again until the legality and legitimacy of constitutional amendment are better aligned.

\section{Legality, legitimacy and amendment rigidity}

If not entirely anomalous in the time and place of Confederation, the Constitution's failure to provide amendment rules was incapacitating over time. Negotiating a textual formula after independence was essentially an exercise in defining the nation's sovereignty because constitutional rules are "the most basic expression of the legal nature of the country". ${ }^{88}$ By the time of the patriation crisis, the protracted lack of consensus on that core question of constitutional sovereignty showed, contrary to perception, that Canada's independence after 1931 may have been "illusory" and that the roots of our legal existence were "virtually untraceable". ${ }^{89}$ The terms of independence would and could not be determined until conflict and confrontation forced a resolution that was costly for constitutional legitimacy.

The impasse on amendment was an impasse on legality, on legitimacy, and, more fundamentally, on how Canadian constitutional sovereignty should be defined. In circumstances of deeply divergent conceptions of constitutionalism, perhaps the impasse could only be broken by a frontal challenge to entrenched assumptions about the role of the provinces in the process of

\footnotetext{
${ }^{87}$ Richard Albert, "The Difficulty of Constitutional Amendment in Canada", supra note 8 (arguing that in combination Canada's formal and extra-textual requirements makes the constitution "exceedingly rigid" and perhaps more rigid than the US Constitution).

${ }^{88}$ Romanow, Whyte and Leeson, Notwithstanding, supra note 7, pp.163.

${ }^{89}$ Ibid, pp. 164.
} 
constitutional amendment. ${ }^{90}$ To continue the speculation, the legitimacy fallout from patriation might have been averted had the proposal for a referendum been more a matter of conviction than a bargaining ploy. It is not difficult to imagine how the legitimizing influence of popular ratification might have altered the patriation narrative and the Constitution's evolution after 1982. ${ }^{91}$ To further probe the follies of amendment in this period, the Constitution's legitimacy sorrows also might not have deepened, after 1982, had the Meech Lake Accord not attempted heroics to reconcile Quebec to the Constitution and, in doing so, profoundly misread the mood of the country. And had some of these missteps been avoided, the spectacle of Charlottetown's defeat in a national referendum might have been spared. The legitimacy deficits that haunt the process today might be attenuated, if not all but eliminated.

Patriation and the Accords were high-stakes initiatives, and each gambled in its own way on the legitimacy of constitutional reform. Legitimacy deficits that were unquestionably situational found strong voice in the fractures, expectations, demands and emotions in play at a time when Canada's survival was in peril. Those dynamics spiralled during the patriation crisis and could not be contained when the follow-up Accords were proposed. These "current states of affairs" or factual rigidities are compelling, but do not separate the post-textual period from the

\footnotetext{
${ }^{90}$ As then Prime Minister Trudeau shrugged, "My answer is there had been a hell of a lot of nice guys since 1926 ... and the constitution was never patriated. Maybe it took a nasty guy". Graham, The Last Act, supra note 7, pp. 41.

${ }^{91}$ See generally Russell, Odyssey, supra note 7 (sub-titled, Can Canadians Become a Sovereign People?); see also Bruce Ackerman and Robert Charney, "Canada at the Crossroads", U.T.L.J., 34:2 (1984), 117-135 (stating that, "although aware of the legitimating power of a national referendum" (129), the referendum proposal was "compromised away" and "rather than appeal to the People ... Trudeau merely appealed to his fellow parliamentary sovereigns"); McWhinney, Canada and the Constitution, supra note 7 (describing the "'people's' route, via a referendum ... as one of the great 'might-have-beens' of the patriation conflict).
} 
longer history of constitutional amendment. ${ }^{92}$ Rather, it has been a central purpose of this article to show that Canada's experience of amendment in and after 1982 is vitally connected to the primal challenge since Confederation in 1867 , and that has been to define the terms of Canada's amendment sovereignty. That could and can only be done by bringing the legality and legitimacy of constitutional change into alignment.

As noted above, a flourishing literature on amendment theory analyzes textual variables to determine, by quantitative and comparative measures, how amendment rules predict or determine the rigidity of constitutional change. ${ }^{93}$ It is telling that Part V's amendment rules place Canada at the end of the textual spectrum for amendment rigidity, but even more telling that a textual measure can so dramatically understate the obstacles to constitutional change. In principle, textual singularity is incomplete as a measure of amendment rigidity because it fails to a host of non-quantitative elements - including situational or factual rigidities - which may play a determinative role in enabling and disabling constitutional change. ${ }^{94}$ Significantly, it also fails to account for amendment rigidities which are grounded in legitimacy deficits that compromise or subvert the process of change. These points have particular salience for Canada's amendment history.

In Canada's case, the rigidity of constitutional amendment reveals an intriguing interaction of textual and non-textual elements. If it is agreed that Part V's rules set Canada's

\footnotetext{
92 Fallon, "Legitimacy", supra note 21. See also Contiades and Fotiadou, supra note 14, pp. 460 (referring to these as "factual rigidities").

${ }^{93}$ Supra note 13.

${ }^{94}$ Supra note 14.
} 
scheme of constitutional legality at the rigid end of the amendment spectrum, it can now be noted that a different kind of rigidity characterizes the pre-textual regime of statutory legality. That rigidity is negative rather than positive in nature because it arose, not from the constraints of rules, but from their absence and its implications for the process of amendment. In addition, Canada's amendment history experienced non-textual rigidities arising from the negative rigidity of text, in the form of deficits in constitutional legitimacy. The inability to articulate and agree on a scheme of amendment legality was a failure in the legitimacy of amendment which created conditions of extreme rigidity. That cycle of dysfunction could and would not be broken without the conflicts of patriation and the two Accords. In addition to the textual rigidities of Canada's complex requirements of constitutional and statutory legality, the rigidities associated with unresolved legitimacy deficits remain in place today.

This, then, is the object lesson for Canada, and for theories of amendment and amendment rigidity more generally. Just as a regime of legality is necessary to legitimize amendments to a constitutional text, legality has limits and is not sufficient where extra-textual legitimacy deficits undermine the authority and acceptability of constitutional change. 